IZA DP No. 8346

Skill Disparities and Unequal Family Outcomes

Shelly Lundberg

July 2014 


\title{
Skill Disparities and Unequal Family Outcomes
}

\author{
Shelly Lundberg \\ University of California, Santa Barbara, \\ University of Bergen and IZA
}

\author{
Discussion Paper No. 8346 \\ July 2014
}

IZA

\author{
P.O. Box 7240 \\ 53072 Bonn \\ Germany
}

Phone: +49-228-3894-0

Fax: +49-228-3894-180

E-mail: iza@iza.org

Any opinions expressed here are those of the author(s) and not those of IZA. Research published in this series may include views on policy, but the institute itself takes no institutional policy positions. The IZA research network is committed to the IZA Guiding Principles of Research Integrity.

The Institute for the Study of Labor (IZA) in Bonn is a local and virtual international research center and a place of communication between science, politics and business. IZA is an independent nonprofit organization supported by Deutsche Post Foundation. The center is associated with the University of Bonn and offers a stimulating research environment through its international network, workshops and conferences, data service, project support, research visits and doctoral program. IZA engages in (i) original and internationally competitive research in all fields of labor economics, (ii) development of policy concepts, and (iii) dissemination of research results and concepts to the interested public.

IZA Discussion Papers often represent preliminary work and are circulated to encourage discussion. Citation of such a paper should account for its provisional character. A revised version may be available directly from the author. 


\section{ABSTRACT}

\section{Skill Disparities and Unequal Family Outcomes}

The prevalence and stability of marriage has declined in the United States as the economic lives of men and women have converged. Family change has not been uniform, however, and the widening gaps in marital status, relationship stability, and childbearing between socioeconomic groups raise concerns about child wellbeing in poor families and future inequality. This paper uses data from a recent cohort of young adults - Wave IV of the National Longitudinal Study of Adolescent Health - to investigate whether disparities in cognitive ability and non-cognitive skills contribute to this gap. Blinder-Oaxaca decompositions of differences in key family outcomes across education groups show that, though individual non-cognitive traits are significantly associated with union status, relationship instability and single motherhood, they collectively make no significant contribution to the explanation of educational gaps for almost all of these outcomes. Measured skills can explain as much as 25 percent of differences in these outcomes by family background (measured by mother's education), but this effect disappears when own education is added to the model. Both cognitive and non-cognitive skills are strongly predictive of education attainment but, conditional on education, explain very little of the socioeconomic gaps in family outcomes for young adults.

JEL Classification: $\quad 124, \mathrm{~J} 12, \mathrm{~J} 24$

Keywords: marriage, family, non-cognitive skills, cognitive ability, inequality

Corresponding author:

Shelly Lundberg

Department of Economics

University of California, Santa Barbara

Santa Barbara, CA 93106-9210

USA

E-mail: slundberg@ucsb.edu

\footnotetext{
* An earlier version of this paper was presented at the 2014 AEA Meetings in Philadelphia. I would like to thank Richard Startz, Gabriella Conti, and participants in the IZA Workshop on Gender Convergence and seminars at the University of Mannheim and University of Zurich for valuable comments on this project. I also appreciate the excellent assistance and comments I have received from Jenna Stearns.
} 


\section{Introduction}

American families differ from families in other Western nations along several dimensions.

Americans marry and cohabit at younger ages, and are more likely to marry at some point in their lives, but marital and cohabiting relationships are also much more likely to dissolve than is the case in other wealthy countries (Cherlin, 2009). Important outcomes of this relationship fragility include a very high rate of single parenthood in the United States, and a high probability that American children will experience the breakup of their parents. ${ }^{1}$ During the past several decades, declining rates of marriage in the United States have been accompanied by a growing divergence in family behavior across socioeconomic groups, with much higher rates of early and single motherhood and marital dissolution among the less-educated and in lowincome communities (McLanahan, 2004; Lundberg and Pollak, 2014). Both the level of family instability and its socioeconomic gradient raise concerns about the well-being of children subjected to disruption in both contact with parents and living arrangements, and about the persistence of economic inequality. In a recent descriptive analysis of intergenerational economic mobility in the U.S., for example, Chetty et al. (2014) find a strong geographic correlation between upward mobility and local measures of family structure such as rates of single parenthood.

A rapidly growing literature has linked adult disparities in economic, health, and social outcomes to gaps in both cognitive and non-cognitive abilities, and has established that these gaps begin to emerge early in childhood (Cunha, Heckman, Lochner, and Masterov, 2006; Duncan and Magnuson, 2011; Conti and Heckman, 2010). ${ }^{2}$ Various studies have documented the importance of non-cognitive attributes such as persistence, self-control, and social skills in contributing to positive adult outcomes. Psychologists have shown that personality traits, in particular, are related to relationship quality and stability (Roberts et al., 2007; Lahey, 2009). These findings raise a further question: Can some part of the socioeconomic inequality in family outcomes, particularly differences in relationship instability and single motherhood, be explained by gaps in non-cognitive skills that contribute to both economic status and to stable families?

A key finding from the Fragile Families and Child Wellbeing Study, which surveyed a large sample of unmarried couples who gave birth between 1998 and 2000, was that a very large fraction of unmarried parents were romantically involved and intended to marry at the time of the birth. Most of these relationships dissolved quickly, however, and only a small fraction actually married (Carlson et al., 2005). One explanation for this discrepancy between stated intentions and actual behavior is that low-income couples lack the relationship skills to overcome the economic and social challenges confronting their familybuilding efforts. Beginning in 2006, the federal government has funded programs designed to foster

${ }^{1}$ Cherlin (2009) tellingly notes that American children born to married parents in the United States are more likely to see their parents break up than are Swedish children born to cohabiting parents (p. 18).

${ }^{2}$ More controversially, Chua and Rubenfeld (2014) attribute the differential success of ethnic groups in the U.S. to variation in culturally-induced traits such as impulse control. 
relationship skills but the results have been disappointing in terms of measurable impacts on relationship quality and marriage. A randomized treatment evaluation of one of the first major programs targeted at unmarried couples, Building Strong Families, found no effect of program access or participation on relationship quality, relationship outcomes, or the probability of marriage (Wood et al., 2012). Even if the skills that enhance relationship quality and stability cannot be easily taught, however, individuals who possess psychological traits that enhance negotiating ability and self-control may experience more positive family outcomes.

In this paper, I examine the determinants of young adult relationship histories and current family status from Wave IV of the National Longitudinal Study of Adolescent Health (Add Health). This survey includes a rich set of individual traits related to motivation, interpersonal styles, and emotional responses, including a Big 5 personality inventory. There are distinct socioeconomic gradients in these traits: less educated individuals (and those with less-educated parents) tend to be less emotionally stable, agreeable, and open to experience, and to have a more external locus of control. There are also significant differences across education groups, as expected, in relationship stability and rates of single motherhood. If personal skills are important drivers of both educational attainment and family outcomes, then skill disparities may explain the differences in family behavior across education groups. I find, however, that observed variations in non-cognitive traits make no significant contribution to most family outcome gaps by education level. The exceptions are very limited: non-cognitive traits explain close to half of the small difference in cohabitation rates between men with high and low levels of education, and less than 10 percent of the gap in single motherhood between women with high and medium education levels. Cognitive skills and risk aversion are also unimportant in explaining gaps in family outcomes across education groups.

Non-cognitive traits do explain significant shares of the divergence in single motherhood and relationship instability for women across family background groups, but these effects appear to be entirely due to the strong relationship between non-cognitive skills and own educational attainment (Lundberg, 2013ab). Educational attainment itself and the opportunities that are associated with education appear to be an important driver of family outcomes, but there is little evidence that non-cognitive skills have substantial effects on family outcomes conditional on education.

\section{Economic Gender Convergence, Marital Surplus, and Socioeconomic Divergence in Family Outcomes}

There have been dramatic changes in American family life since the post-war years of the baby boom: increasing age at first marriage and declining marriage rates, a divorce rate that peaked around 1980 and remains high, and decreasing fertility that is more likely to occur outside of legal marriage. Contributing factors have undoubtedly included the decline in male-female gaps in market work and 
earnings, which have decreased the gains to gender specialization in households. Notably, the retreat from marriage has been much more pronounced among men and women with lower levels of education (Lundberg and Pollak, 2014). Both marriage and remarriage rates have risen for women with college degrees relative to women with less education, and the fall in divorce rates since 1980 has been much larger for the college educated (Isen and Stevenson, 2011). This implies that long-term marital stability also has a pronounced education gradient: the probability that a first marriage will remain intact for 20 years is sharply higher for women with a college degree (78 percent) than for women with a high-school diploma (41 percent) or some college (49 percent) (Copen et al., 2012). The prevalence of cohabitation is strongly decreasing in education, and cohabitation tends to play different roles in the lifecycles of women with high and low levels of education. For high-education couples, cohabitation is usually a precursor to marriage that rarely includes childbearing, while for less-educated couples it is often a (relatively unstable) context for bearing and rearing children (Lundberg and Pollak, 2014).

The growing divergence in marriage, cohabitation, and fertility behavior across educational groups has potentially important implications for inequality and the intergenerational transmission of economic disadvantage. The rise in single-parent families and changing patterns of relationship instability and maternal age have resulted in growing disparities in the parental resources, both time and money, received by the children of more- and less-educated mothers (McLanahan, 2004). The children of the non-college educated are particularly disadvantaged by the instability in living arrangements and parental ties that result from the more frequent partnering and re-partnering of their mothers (Cherlin, 2009).

Though the increasing socioeconomic discrepancies in marriage, non-marital childbearing and marital stability have been extensively documented, their source remains somewhat of a mystery. One possibility is that, as the sources of marital surplus have altered with the decrease in gender specialization, there has been a relative decrease in the surplus available to low-income couples. An alternative explanation would emphasize the increasing importance of social and behavioral skills-self-control, conflict resolution, etc.-in maintaining marriages as rigid social norms about cohabitation and childbearing outside marriage have weakened.

\section{Declining Marital Surplus}

As women's educational attainment, wages, and hours of market work have risen relative to men's, the opportunities for gains from trade within a household, which depend to a large extent upon the segregation of men and women in market and home sectors, have diminished-and so have the potential gains to marriage. Gender specialization in married couple households has decreased dramatically over the past 60 years and, it has been argued, the source of marital gains have shifted from production complementarities associated with home and market work to the consumption complementarities of the "hedonic" marriage (Stevenson and Wolfers, 2007; Lundberg and Pollak, 2007). The decline in the value 
of the production-oriented marriage may have been particularly acute at lower income levels, where men's economic prospects have deteriorated more than those of women.

A related story about marital surplus focuses on the role of marriage as a context for childrearing (Lundberg and Pollak, 2014). Although college-educated couples are much less likely than in the past to use marital commitment to support a gender-specialized division of labor, high-education couples may choose marriage as a commitment device that supports joint investments in children. Intensive investment is a characteristic parenting pattern among the well-educated and well-off, and these investments have been increasing both in absolute terms and relative to the investments made by those with less education and fewer resources (Ramey and Ramey, 2010; Kornrich and Furstenberg, 2013). These increases are probably due to some combination of rising returns to human capital as income inequality rises, increasing real incomes at the top of the distribution, and improved information about the payoffs to early child enrichment activities-perhaps reinforced by evolving class-specific parenting norms.

\section{Marital Skills Gap}

Alternatively, the socioeconomic divergence of marital and childbearing behavior may be due to skill gaps between high- and low-income couples. As rigid norms about marriage weaken, the maintenance of a successful marriage may depend more on personal skills such as the ability to commit to an agreement or to negotiate in response to shocks. ${ }^{3}$ This implies that the returns to traits such as self-control, verbal ability, and positive affect may have increased as the social punishments for divorce and non-marital childbearing have decreased. ${ }^{4}$ Individual skills may have also become more important determinants of initial match quality. Certainly, a growing body of research shows that individual traits other than cognitive ability, verbal and math skills are associated with key economic outcomes (Heckman, 2000), and this is likely to apply to social outcomes as well. Perseverance, self-esteem, social competence and self-control can contribute to economic success through an individual's ability to interact effectively with others, to plan ahead and to behave in a controlled and purposeful manner, and there may be considerable overlap between relationship skills in the market and in the home (Kambourov, Siow, and Turner, 2013). The skills that enable individuals to succeed in educational institutions and in employment, therefore, may also contribute to their ability to make a high-quality match or to sustain intimate relationships.

There is no generally-accepted set of observable skills that contribute to relationship competence. One promising candidate among the non-cognitive skill measures identified in the existing literature is the

\footnotetext{
${ }^{3}$ Gottman (1994), for example, finds that relationship quality and stability are strongly related to effective communication and conflict resolution.

${ }^{4}$ Cognitive ability may also be important. Blazys (2009) estimates hazard models of transitions into and out of marriage for men and women in the National Longitudinal Survey of Youth 1979, and finds that cognitive skills delay marriage (principally through increased education) but increase the probability of marriage later in life and reduce the probability of divorce.
} 
personality inventory, developed by psychologists as a reliable and consistent indicator of individual differences in behavioral tendencies. Psychological studies have found that personality traits are extremely stable across the adult lifespan, and that there are strong associations between personality and a broad range of behaviors and economic and social outcomes, including health and mortality, income, and relationship quality and stability (Roberts et al., 2007). For example, Lahey (2009) finds that individuals high in the Big 5 trait Neuroticism are more likely to experience negative life events and find it difficult to maintain supportive social relationships, including marriages. The role of personality differences in explaining socioeconomic gaps in relationship stability and other family outcomes, however, has not been studied.

\section{Data and Measures}

Education gradients in several aspects of relationship history and family status among a recent cohort of young Americans are apparent in the latest wave of data from the National Longitudinal Study of Adolescent Health. ${ }^{5}$ The Add Health study began in 1994-95 with a nationally-representative school-based survey of more than 90,000 students in grades 7 through 12. About 20,000 respondents were followed in subsequent surveys, the last of which (Wave IV) was conducted in 2007-08 when the respondents were between 24 and 32 years of age. Race and ethnic differences in family outcomes are substantial, with black and Hispanic men and women less likely, conditional on education, to be married and more likely to experience single parenthood. To focus on socioeconomic differences in family behavior, the analysis in this paper uses subsamples of 3,831 non-Hispanic white women and 3,483 non-Hispanic white men for whom all key variables are non-missing.

Figures 1a and $1 \mathrm{~b}$ show the proportions of women and men, respectively, in three education groups who are currently married, cohabiting, or in a marital or cohabiting union as of the survey date in Wave IV, have experienced two or more (or three or more) co-residential unions before that time and, for women, are currently a single (unmarried) or lone (neither married nor cohabiting) mother. The education groups are 4-year college degree or more, some college (including holders of 2-year Associate degrees), and high school graduate or less. Education differences in union status are very small-less educated men and women enter into marital and, particularly, cohabiting unions at an earlier age than the more-educated, but those unions tend to be less stable. There are, however, distinct education gradients in relationship

\footnotetext{
${ }^{5}$ Add Health is a program project directed by Kathleen Mullan Harris and designed by J. Richard Udry, Peter $\mathbf{S}$. Bearman, and Kathleen Mullan Harris at the University of North Carolina at Chapel Hill, and funded by grant P01HD31921 from the Eunice Kennedy Shriver National Institute of Child Health and Human Development, with cooperative funding from 23 other federal agencies and foundations. Special acknowledgment is due Ronald R. Rindfuss and Barbara Entwisle for assistance in the original design. Information on how to obtain the Add Health data files is available on the Add Health website (http://www.cpc.unc.edu/addhealth). No direct support was received from grant P01-HD31921 for this analysis.
} 
instability and in single and lone motherhood, with college-graduates being much less likely to experience either status.

With this relatively young sample, comparisons across education groups may be complicated by differences in the life-cycle timing of establishing relationships and households. Figures $2 \mathrm{a}$ and $2 \mathrm{~b}$ graph the age trajectories of the sample means for key outcomes and show that the education differences, except for union status, are consistent over time. All models will include age dummies and interactions between skill measures and age dummies to allow for different trajectories for education groups.

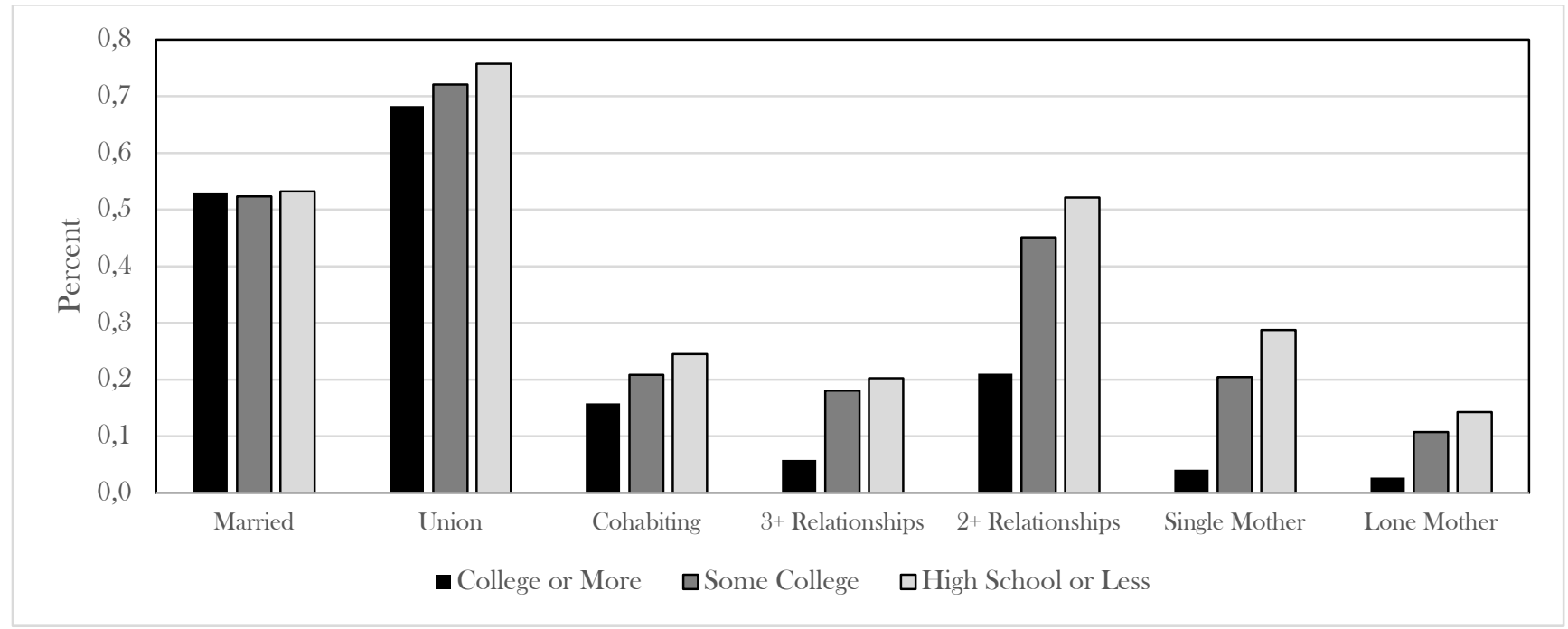

Figure 1a: Women's Family Outcomes, by Education (White, non-Hispanic, Add Health Wave IV)

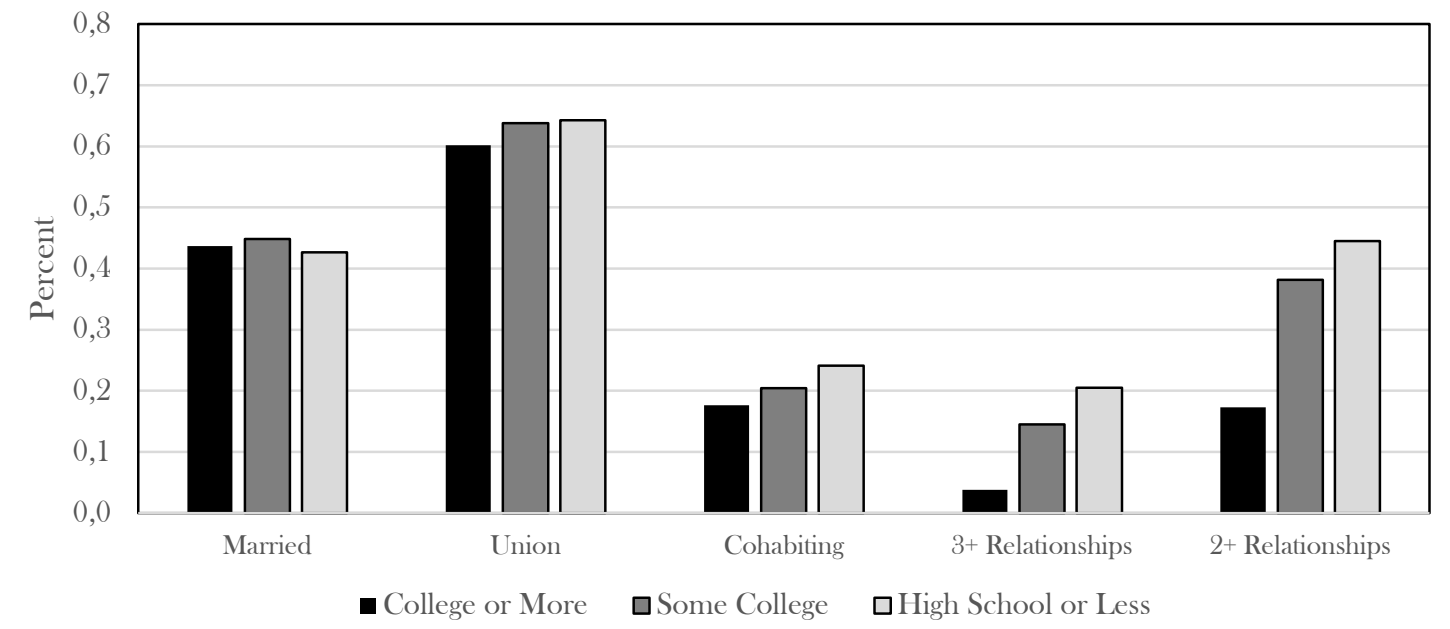

Figure 1b: Men's Family Outcomes, by Education (White, non-Hispanic, Add Health Wave IV) 
Figure 2a: Female Outcomes by Age and Education
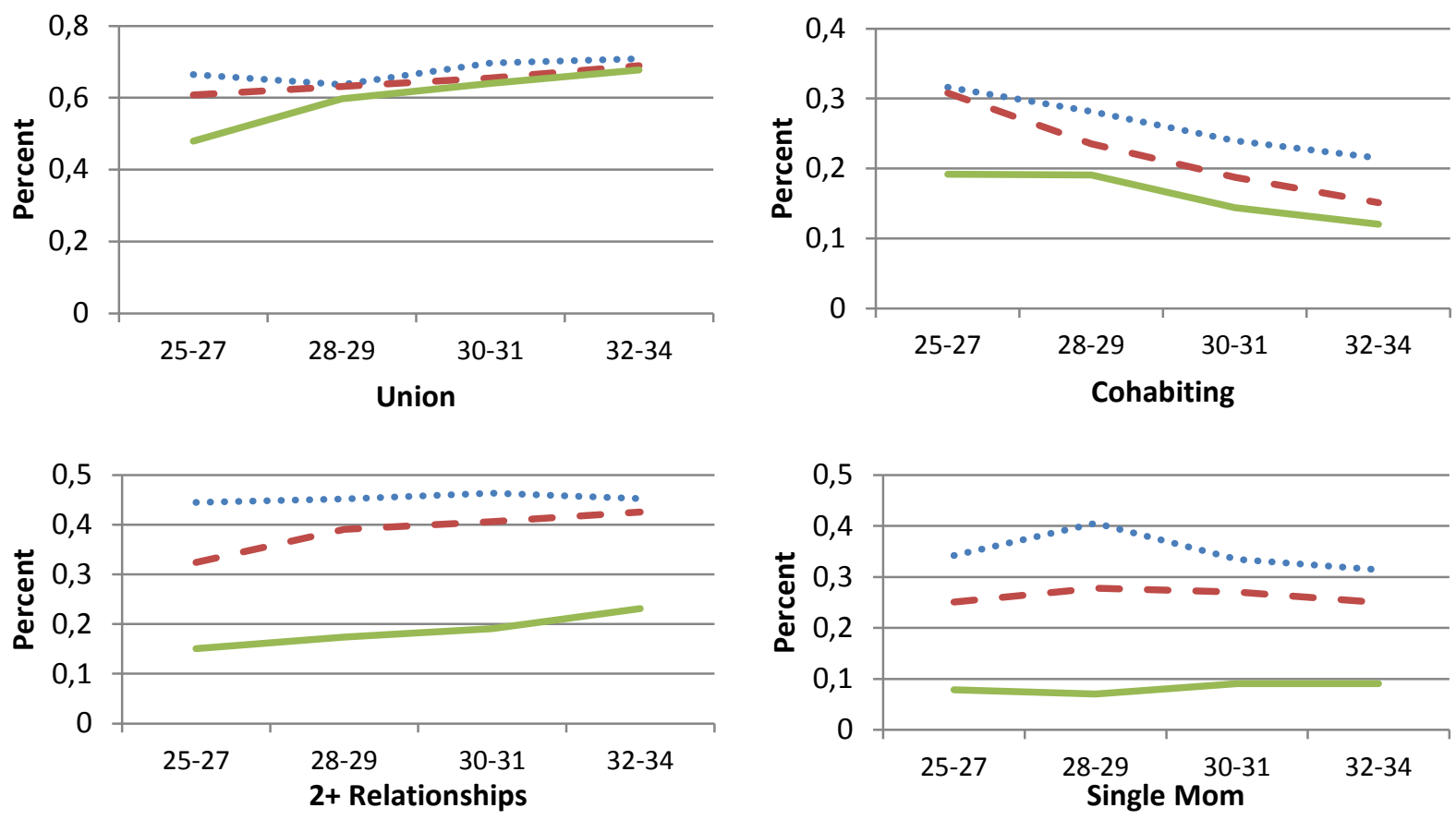

College or More

Figure 2b: Male Outcomes by Age and Education
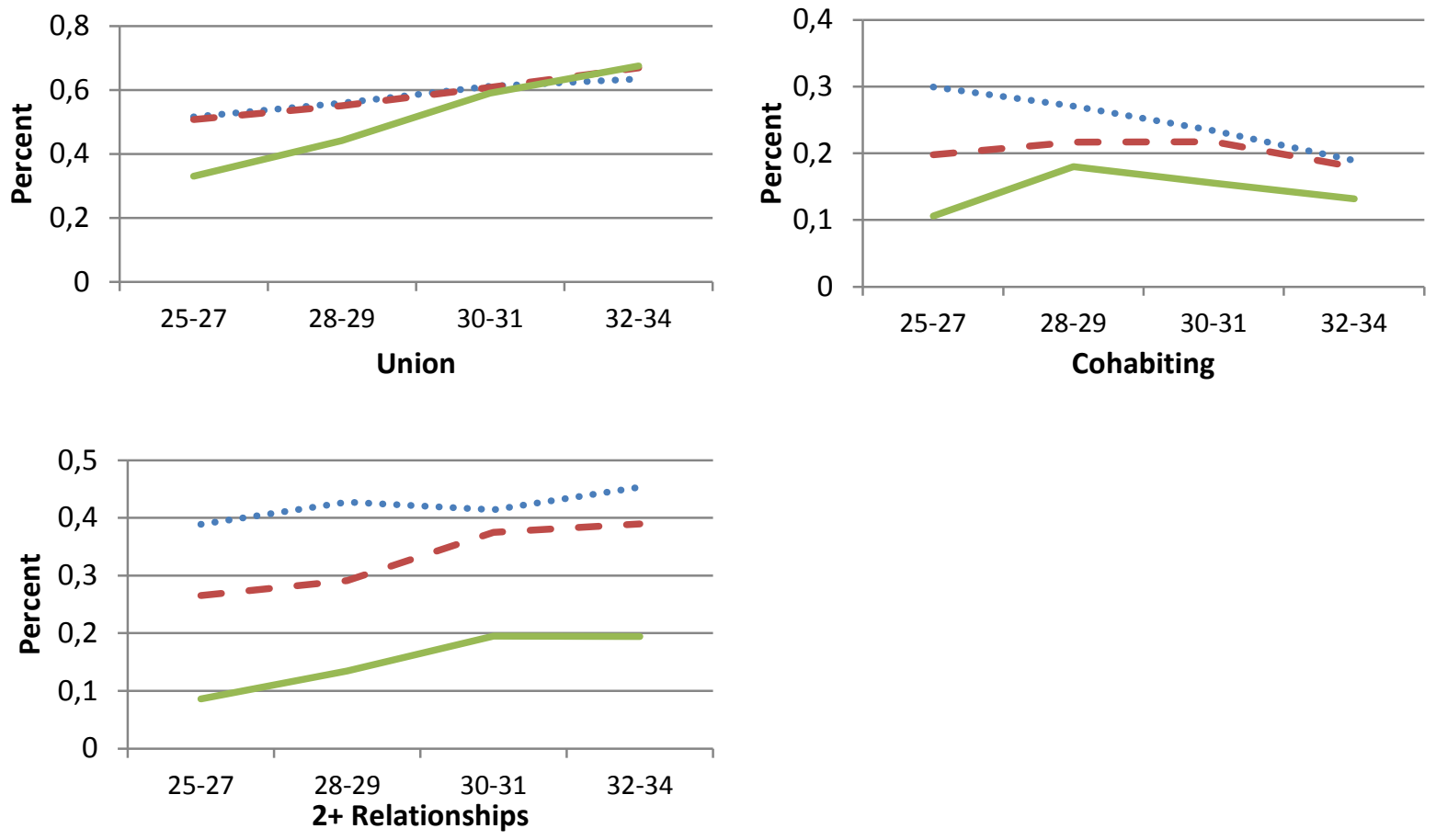

College or More _ - Some College

-... High School or Less 
Non-cognitive Skills: The Add Health Study has collected an unusually rich set of psychological measures that can serve as indicators of non-cognitive ability, as well as several measures of cognitive ability and an index of risk aversion. During Wave IV, a 20-item short-form version of the 50-item International Personality Item Pool-Five-Factor Model (IPIP-FFM) known as the Mini-IPIP was fielded, ${ }^{6}$ and it was supplemented by several other indices of personality facets and other psychological traits. Personality inventories measure individual variation in "the relatively enduring patterns of thoughts, feelings, and behaviors that reflect the tendency to respond in certain ways under certain circumstances” (Roberts, 2009). Five-factor models of personality, and in particular the variant known as the "Big 5" model, are broadly accepted in psychology as meaningful and consistent constructs for describing human differences (Goldberg, 1981). The five factors, with their definitions from the American Psychological Association APA) Dictionary (2007), are:

Openness to Experience (Intellect) - The tendency to be open to new aesthetic, cultural, or intellectual experiences.

Conscientiousness - The tendency to be organized, responsible, and hardworking.

Extraversion - An orientation of one's interests and energies toward the outer world of people and things rather than the inner world of subjective experience; characterized by positive affect and sociability.

Agreeableness - The tendency to act in a cooperative, unselfish manner.

Emotional Stability (vs. Neuroticism) - Predictability and consistency in emotional reactions, with absence of rapid mood changes.

Other psychological measures expected to be predictive of young adult health behaviors and outcomes were also included in the personality section of the Add Health survey in Wave IV. I have included in the set of non-cognitive skills several measures of such traits (below), but have excluded a depression scale and a perceived stress scale from the mental health section of the survey. The questions that these scales are based on refer to how the individual has been feeling during the past 7 days or the past 30 days, and so focus on current emotional states rather than persistent tendencies.

Locus of Control/Mastery - A construct that is used to categorize people's basic motivational orientations and perception of how much control they have over the conditions of their lives (APA Dictionary).

Anxiety and Anger/Hostility- Individual facets of Neuroticism (as identified by Costa and McCrae, 1992) that reflect tendencies to persistently experience apprehension and worry, or to respond emotionally and angrily to frustration or injury.

\footnotetext{
${ }^{6}$ This instrument is discussed, and the specific items listed, in the Data Appendix.
} 
Anger/Hostility and Anxiety are individual facets of the Big 5 trait Emotional Stability (Neuroticism) and the Add Health survey includes sets of questions that focus on these sub-traits. ${ }^{7}$ High levels of the Anger/Hostility trait in particular might be expected to be related to difficulty in maintaining relationships. Individuals with an internal Locus of Control are more likely to behave intentionally and they "perceive their life outcomes as arising from the exercise of their own agency and abilities" (APA Dictionary). Other studies have found that an internal Locus of Control is associated with a variety of positive economic and social outcomes (Plotnick, 1992; Heckman, Stixrud, and Urzua, 2006; Cobb-Clark and Tan, 2011).

Each item in the extended personality inventory is assumed to be is a noisy measure of a single unobserved latent trait. An individual $i$ is characterized by the set of eight non-cognitive traits $T_{i j}$ defined above, and their responses to the $\boldsymbol{K}$ survey questions in the Wave IV survey generate:

$$
t_{i j k}=\beta_{j k} T_{i j}+\varepsilon_{i j k} \quad \text { for } k=1, \ldots, K_{j} \text { and } j=1, \ldots, 8
$$

with measurement errors that are assumed to be independent of each other and of the trait $T_{j} . K_{j}$ is equal to four or five for each of the traits. Factor analysis of the items for each trait produces estimates of the $\beta$ parameters as factor loadings, ${ }^{8}$ and in each case a single-factor model is supported by the data. The factor loadings and error variances from each model are then used to estimate factor scores that are unbiased estimates of each latent non-cognitive trait.

Figures $3 \mathrm{a}$ and $3 \mathrm{~b}$ show the mean values of standardized non-cognitive traits for women and men in different education groups. The relationship between non-cognitive skill and education varies by trait with, among the Big 5 traits, very little variation in Conscientiousness and Extraversion but more significant gradients in Openness, Agreeableness, and Emotional Stability. In general, education is positively correlated with an internal locus of control and negatively correlated with anger/hostility and anxiety. For some traits, the gender gaps dominate the socioeconomic gradient-men are less agreeable and anxious and more open to experience and emotionally stable on average than women.

\footnotetext{
${ }^{7}$ Studies that represent psychopathy as an extreme variant of aspects of the five-factor model of personality have included these facets among the set that characterize this disorder (Miller, Lynam, Widiger, and Leukefeld, 2001). ${ }^{8}$ This analysis is done separately for men and women.
} 


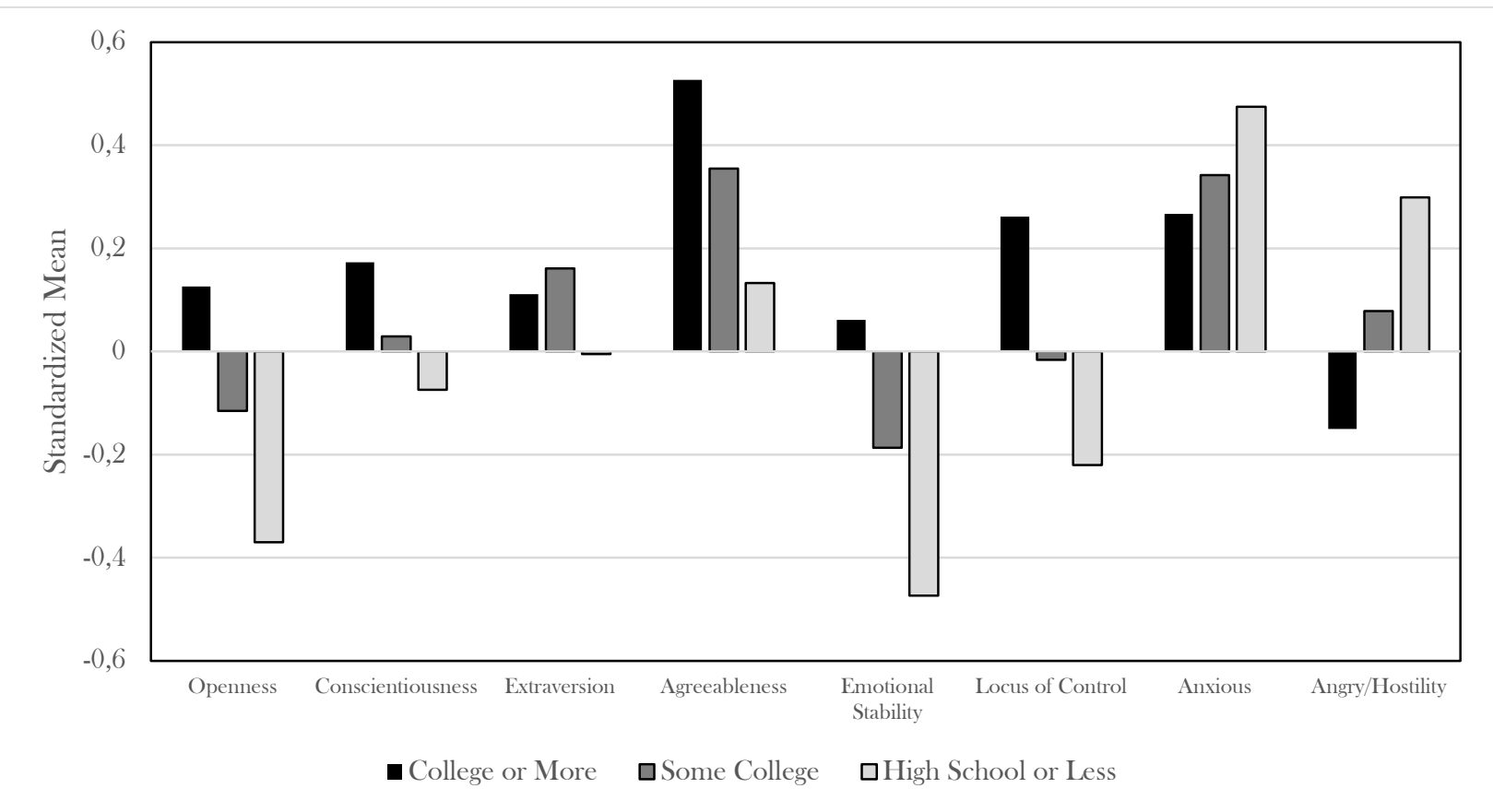

Figure 3a: Non-cognitive Skills by Education Group, Women

(White, non-Hispanic women, Add Health Wave IV)

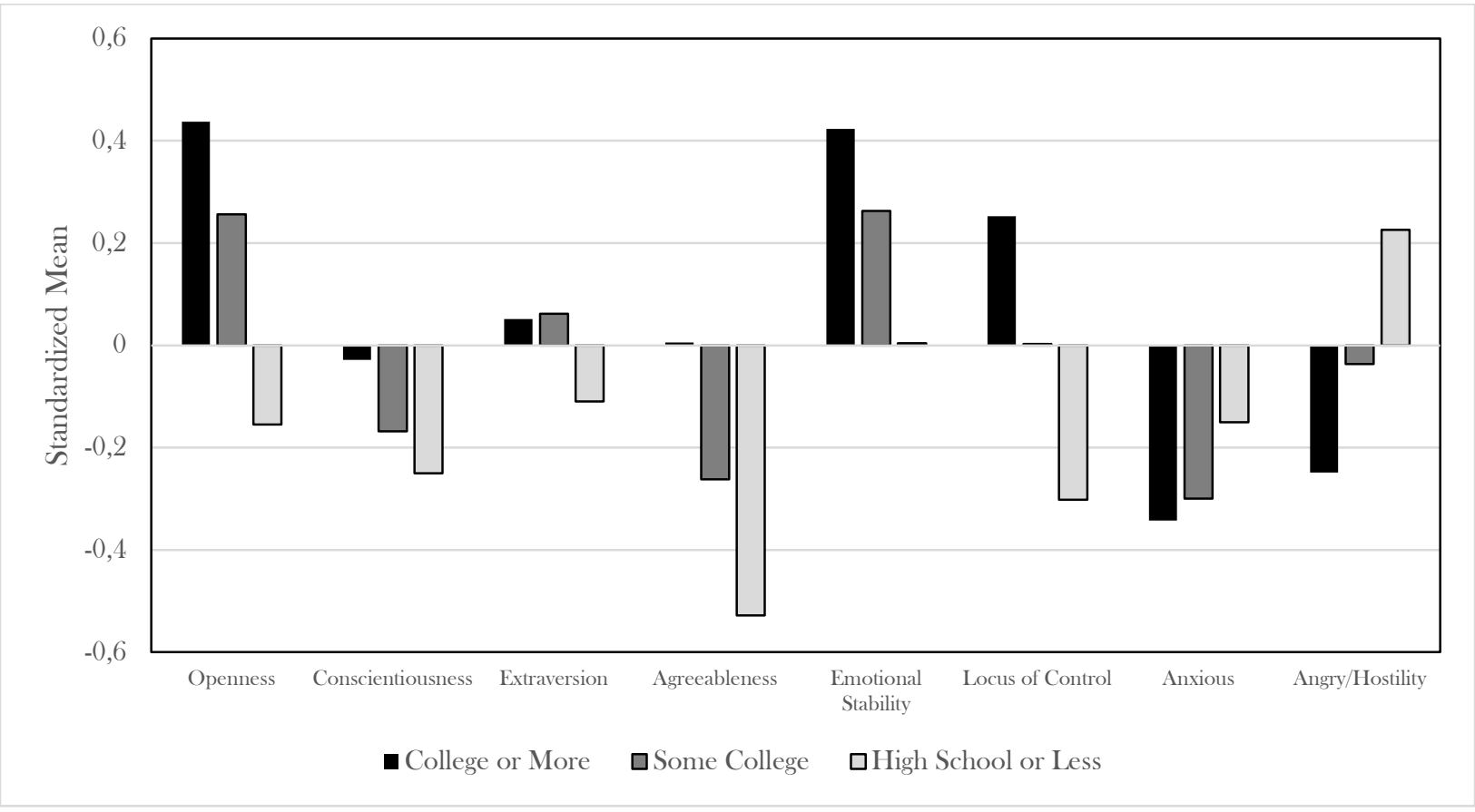

Figure 3b: Non-cognitive Skills by Education Group, Men

(White, non-Hispanic men, Add Health Wave IV) 
Cognitive Ability: Factor analysis is also used to construct a single index of cognitive ability, using a Wave I measure of verbal ability and a set of three Wave IV memory tests. The mean of this standardized variable is about .7 standard deviations greater in the highest education group for both men and women (college graduate or more) than in the lowest education group (high school graduate or less).

Risk Aversion: Evidence is accumulating that personality traits are not simply proxies for economic preference parameters. The empirical associations between personality and preferences are very weak (Almlund et al., 2011; Rustichini et al., 2012) and the two sets of variables have largely independent effects on a large set of outcomes, including health, life satisfaction, wage, unemployment, and education (Becker et al., 2012). The only economic preference measure available in the Add Health study to date is risk aversion, measured by a Likert scale response to the statement "I like to take risks" in the Wave IV questionnaire. Dohmen et al. (2011) examine the validity of a similar single-scale measure of general willingness to take risks in the German Socioeconomic Panel Study and show that it predicts actual risktaking behavior well in investment, career choice, smoking, and other domains. There is no significant association between this measure of risk aversion and education in these samples.

\section{Family Status, Education, and Skills}

Tables $1 \mathrm{a}$ and $1 \mathrm{~b}$ report the coefficients from simple linear probability models for four discrete indicators of family status as of Wave IV-currently in a marital or cohabiting union, in a cohabiting (nonmarital) union, having had two or more marital or cohabiting relationships and, for women, single motherhood. The independent variables are educational attainment, standardized measures of cognitive and non-cognitive skills, and risk aversion. In general, the probabilities of being in a co-residential union, of having had multiple relationships, and of single motherhood are decreasing in education, with college graduation having a substantial negative association with all three outcomes. The effects of education moderate only slightly for most outcomes when skills and preferences are added to the model. The pattern of education effects on current union status clearly reflects the earlier entry of the less-educated, particularly into cohabiting unions. This timing effect outweighs the greater stability of relationships for the moreeducated, and the probability of being in union is higher for the less-educated groups in this young cohort. In this case, the education effects become slightly stronger when skills are added to the model. The Rsquares are low, particularly for union status, and educational attainment accounts for most of the explained variance in the relationship instability and single motherhood models.

There are, however, several non-cognitive traits that are significantly associated with family outcomes. Consistent with earlier studies using German data, Openness decreases the probability of being in a union and increases relationship instability, especially for men (Lundberg, 2012). Emotional Stability, 
as expected, reduces relationship instability and a more internal Locus of Control increases the probability that both men and women are in a marital or cohabiting union. Other effects are gender specific: union status for men is increasing in Extraversion and, oddly, Anger/Hostility and decreasing in Agreeableness. For women, Agreeableness reduces both relationship instability and single motherhood, while Extraversion increases the probability of both outcomes.

Cognitive ability has small significant effects on relationship stability for women and single motherhood when education is not controlled for (not reported here), but these disappear in models that include educational attainment. A significant positive effect remains only on men's union status, and additional analysis shows that this occurs via an increase in legal marriage. Risk aversion has robust positive effects on union status and negative effects on relationship instability for both men and women. These results are consistent with previous studies showing that risk aversion is positively associated with marriage (Schmidt, 2008; Spivey, 2010) and negatively associated with divorce (Light and Ahn, 2010; Lundberg, 2012).

In general, these models confirm that there are large disparities in family outcomes between young college-educated Americans and those with lower levels of education. Less-educated men and women are more likely to co-reside as young adults, particularly in non-marital unions, and more likely to experience multiple cohabiting relationships by their late twenties and early thirties. Less-educated women are more likely to be single mothers. Though we observe distinct educational gradients in many of our measures of cognitive and non-cognitive skills, and there are a number of significant skill-family relationships that are intuitively plausible and consistent with the findings of previous studies, the education gaps in family outcomes are reduced only slightly when a large set of skill measures are included in the model. This preliminary analysis suggests that education differences in skills are likely to explain very little of the observed differences in family behavior between college graduates and others.

\section{Decomposing the Socioeconomic Gap in Family Outcomes}

The regression models in the previous section do not allow for the possibility that the returns to skills in generating relationship stability and other family outcomes may vary across socioeconomic groups. In this section, the mean differences in family outcomes across education and family background groups are decomposed into components that can be "explained" by group differences in skills and preferences and residuals that are due to group differences in the model parameters, including the constant term. A Blinder-Oaxaca decomposition is implemented with linear probability models for each of the outcomesunion status, cohabitation, relationship instability, and single motherhood. Basing the decomposition on a pooled model (that includes a separate intercept for each education group, as suggested by Fortin (2008)) 
allows a two-fold decomposition of the family gaps into explained and unexplained portions without an additional interaction term. ${ }^{9}$

The family outcome for individual $i$ in education group $k$ is modelled as a linear function of a vector of non-cognitive skills, cognitive ability, and risk aversion $Z_{i k}$, a set of age dummies $A_{i k},{ }^{10}$ and a full set of interactions between the age dummies and the individual's skills and preferences to allow for different life-cycle trajectories across groups.

$$
Y_{k i}=X_{k i} \beta_{k}=Z_{k i} \beta_{k z}+A_{k i} \beta_{k a}+\left(A_{k i} \cdot Z_{k i}\right) \beta_{k r}
$$

The difference in education group means can be decomposed into a term due to differences in characteristics (valued at the estimated coefficients from the pooled model, and two terms that reflect differences in the returns to skills and preferences and differences in the age trajectory of this outcome across groups, relative to the pooled model. The gap in outcome $\mathrm{Y}$ between the college group $(C)$ and the high-school group $(H)$ can be expressed as:

$$
\bar{Y}_{C}-\bar{Y}_{H}=\left(\bar{X}_{C}-\bar{X}_{H}\right) \hat{\beta}_{P}+\bar{X}_{C}\left(\hat{\beta}_{C}-\hat{\beta}_{P}\right)+\bar{X}_{H}\left(\hat{\beta}_{P}-\hat{\beta}_{H}\right)
$$

where $\hat{\beta}_{P}$ is the estimated coefficient vector from the pooled model. Each of these terms can be further sub-divided into portions attributable to individual variables or coefficients, or to sets of variables and coefficients.

By Own Education: Table 2 shows the decomposition of the college-graduate vs. some college gaps in union status, cohabitation, relationship history, and (for women) the probability of single parenthood, while Table 3 reports the college-graduate vs. high school and below decomposition. Group membership in this application is not exogenous-what we would like to know is the extent to which educational differences in family outcomes are attributable to measured differences in skill sets across groups. In the same way that a decomposition of the union-nonunion wage differential separates the wage gap into portions explained to observed worker characteristics and an "unexplained" portion potentially attributable to union status itself, this exercise establishes a bound on the importance of skills as determinants of socioeconomic gaps in family outcomes. ${ }^{11}$

The first three lines of Tables 2 and 3 show the average levels of each dichotomous variable for the two education groups and the raw difference. These are followed by the gaps that can be explained by differences in characteristics and by differences in coefficients, with the proportion of the gap explained

\footnotetext{
${ }^{9}$ This is implemented in Stata with the "pooled" option of the oaxaca command. This command and its variants is described in Jann (2008), who also derives the variance estimators for the decomposition.

${ }^{10}$ The age dummies are for the intervals 27 to 28,29 to 30, and 31 and over, with under 27 the omitted category.

" For a discussion of identification issues in decomposition analyses of this type, see Fortin, Lemieux, and Firpo (2011).
} 
shown in bold and in brackets. The difference in characteristics is divided into group differences in noncognitive skills, cognitive ability, and risk aversion. Each of these terms includes the trait/age interactions as well as the standardized level. Since the average age varies little across groups, age is not included in the set of characteristics reported. Components due to differences in the coefficients on age and the constant term are also reported separately.

As we have seen, the mean differences between educational groups in the probability of being in a marital or cohabiting union are small: less-educated men and women are more likely to enter into such a union at an early age, but more likely to experience the dissolution of these unions than more-educated individuals. On average, men and women with a high school diploma or less are 7 percentage points more likely to be in a union than college graduates (Table 3). Men and women with some college are also more likely than graduates to be in a union, but these differences are smaller and, for women, not significant (Table 2). In 3 of the 4 cases, these mean group differences can be attributed entirely to differences in the model coefficients, which explain more than 100 percent of the differences. Differences in non-cognitive skills and risk aversion between the education groups, rather than contributing to the union status gaps, work in the opposite direction. For example, college-educated women have characteristics that make them more likely to be in a co-residential union than women with some college (column 1, Table 2), but the difference in constant terms predicts much higher union status for the less-educated group. This effect, in turn, is mostly offset by the different age trajectories, since the college-educated tend to catch up in coresidence rates as they enter their thirties. The pattern is similar for men's union status and the high-low education comparison for women, but in these cases the contribution of differences in characteristics to explaining the gaps are insignificant.

Differences across education groups in the proportion of men and women who are cohabiting are also rather small, and in three of the four comparisons, skills and preferences make no significant contribution to explaining these differences. The exception is the high-low education decomposition for men reported in Table 3. In this case, non-cognitive skill differences explain more than 40 percent of the higher cohabitation rate of men with a high school education or less, compared to college-educated men. This is consistent with the simple regression models of male cohabitation in Table $1 \mathrm{~b}$, which show that including skills substantially reduces the education coefficients.

The education gaps in our measure of relationship instability are both substantial and significant: men in the lowest educational group are 27 percentage points more likely to have experienced two or more marital or cohabiting unions by Wave IV, and women with a high-school diploma or less are 32 percentage points more likely to have had two relationships than female college graduates (Table 3 ). In each case, however, observed skills and preferences make no significant contribution to the explanation of these gaps. The differences in the constant term and the age trajectory make a joint contribution to the education gap 
that is equal to or greater than the mean differences between groups, and the proportion of the gap attributable to coefficient differences exceeds 90 percent in each case.

The decompositions of the substantial education gaps in the probability of being a single mother in Wave IV yield consistent, though modest, effects of non-cognitive skill differences-accounting for 7 or 8 percent of the mean group differences in both the high-medium and high-low comparisons. These models provide the strongest evidence for the relevance of skill differences in explaining family gaps. Overall, differences in cognitive skills and non-cognitive traits play a surprisingly limited role in explaining educational differences in a broad set of family outcomes, beyond their effects on education itself.

Alternative specifications of the model demonstrate that these results are robust. Allowing for nonlinearities in the effects of non-cognitive skills by including dummy variables for values greater than or less than one standard deviation from the mean for each trait has extremely small effects on the explanatory power of characteristics. Decompositions of the socioeconomic gaps in other family outcomes, such as having experienced a divorce or separation, a history of three or more cohabiting or marital relationships, and being a lone (non-cohabiting) mother, yield very similar patterns of results with modest or no significant contribution of skills and preferences. Standard Blinder-Oaxaca decompositions based on a logit model (using either the high or low education sample as the reference group) show that the results are not, in general, sensitive to the linear probability model framework. Some estimates, particularly for the union outcome, vary substantially depending on whether the high or low group coefficients are used as weights, but the relationship stability and single motherhood decompositions are particularly robust. ${ }^{12}$

A possible concern with using Wave IV personality measures as non-cognitive skills that predict family outcomes is that these traits may have been directly shaped by youthful experiences. There is no standard personality inventory available in Wave I of Add Health, but psychologists Young and Beaujean (2011) used a set of Wave I survey items with a lexical relationship to Five Factor Model questions in standard scales to construct Wave I-based measures of Emotional Stability/Neuroticism, Conscientiousness, and Extraversion. Substituting these partial Wave I-based personality traits for the Wave IV measures reduces the explanatory power of differences in characteristics for family outcomes both in the simple linear models of Table 1 and in the decompositions.

Differences across education groups in cognitive and non-cognitive skills fail to account for a substantive fraction of gaps in family outcomes between college-educated and other men and women and in most cases they make no significant contribution. Overall, these results provide little support for the hypothesis that socioeconomic differences in important family outcomes are being driven by disparities in skills that contribute to both educational success and family stability. In each of these decompositions,

\footnotetext{
${ }^{12}$ The logit models were estimated using the nldecompose module in Stata (Sinning, Hahn, and Bauer, 2008). The family background decompositions were also very similar across the linear probability and logit specifications.
} 
almost all of the action is in the constant terms (and in some cases, the age trajectory). Education itself, rather than skills and preferences that are correlated with education, appears to be the source of differences in the stability of relationships and in single motherhood.

By Family Background: Both cognitive and non-cognitive skills have substantial effects on educational attainment in the Add Health sample (Lundberg, 2013ab), and so it is possible that these skills are important drivers of family status through this channel. By redefining groups on the basis of the mother's educational attainment and estimating decomposition models that are both conditional and unconditional on own education, we can investigate the roles of both skills and own education in driving the relationship between family background and family outcomes. In these models, skills are allowed to have both indirect effects on family outcomes via their impact on educational attainment, and direct effects conditional on education level. Since the gaps in union status by maternal education are extremely small, group decompositions for this outcome are not reported.

Table $4 \mathrm{a}$ and $4 \mathrm{~b}$ report the decompositions of family outcomes across family background groups for women and Table $5 \mathrm{a}$ and $5 \mathrm{~b}$ show similar results for men. The average education level of mothers is lower than that of the Add Health respondents, and so the three education groups are adjusted downwards to some college or more, high school, and less than high school to maintain adequate sample sizes. The first column in each table decomposes the differences in educational attainment (in years completed) across family background groups. Then two variants of each family outcome model are estimated: one includes just skills and risk aversion as explanatory variables, and the other includes own educational attainment as an independent variable.

The first column in each table shows the contribution of observed skills vs. model parameters in explaining educational attainment differences across family background groups. The disparity in educational attainment between the high and medium mother's education groups is about 1.4 years for both men and women, and the gap between the high and low mother's education groups is 2.8 years for women and 2.6 years for men. Between 15 and 22 percent of these gaps can be explained by disparities in noncognitive skills and cognitive ability across these groups, with the impacts of each skill set about equal in each case. This provides a sharp contrast with the previous analysis, in which individual traits appeared to be relatively unimportant in explaining family outcome discrepancies across own education groups. Skills are important drivers of family background differences in educational attainment.

Turning to the decompositions of family outcome differences, we can see that in the models that do not include education, individual skills play no significant role in explaining differences in male or female cohabitation rates or male relationship instability by family background. Skills and preferences do explain 12-15 percent of the gaps in single motherhood, however, (Tables $4 \mathrm{a}$ and $4 \mathrm{~b}$ ) and 25 percent of the gap in relationship instability between the high and low family background groups (Table $4 \mathrm{~b}$ ). When own 
educational attainment is included in the model, however, it becomes clear that the apparent significance of cognitive and non-cognitive skills in the prediction of family outcomes is an indirect effect through their impact on education. Education increases the "explained" proportion of the gap dramatically (in most cases to at least 80 percent) while eliminating the independent contribution of skills.

The relative unimportance of non-cognitive skills in explaining socioeconomic gaps in important family outcomes such as marital stability and single motherhood (beyond their effects on education) is made even more surprising by the possibility that traits measured in adulthood may have been influenced by the relationship history of the individual. There is considerable evidence that Big 5 personality traits are remarkably stable over the adult lifecycle, ${ }^{13}$ but some malleability in adolescence cannot be ruled out. When the decomposition analyses are repeated using only Wave I measures of non-cognitive and cognitive skills, the pattern of results is very similar to the Wave IV variant.

\section{Conclusions}

Concerns that falling marriage rates and rising non-marital childbearing in low-income communities in the U.S. may be exacerbated by deficits in non-cognitive abilities such as self-control and communications skills have given rise to (apparently unsuccessful) federal programs that attempt to foster relationship skills among the poor. However, a growing literature in economics and psychology documents the importance of non-cognitive skills and personality traits for a broad set of economic and social outcomes, including family status, suggesting that these skills may play an important role in the establishment and maintenance of intimate relationships.

This paper investigates the role of skills in explaining socioeconomic gaps in family history and family status for a recent cohort of young adults. A standard decomposition analysis using the Add Health data shows that even though individual non-cognitive traits, such as personality and locus of control, are correlated with family outcomes such as relationship instability and single motherhood, differences in these traits fail to explain any significant portion of most family gaps across education groups. Defining socioeconomic groups by mother's education allows skills to have both direct effects on family outcomes and indirect effects through own educational attainment. A decomposition of differences across these family background groups shows that the relationship between non-cognitive skills and family outcomes depends almost entirely on the indirect route--these skills are strong predictors of educational attainment but their effects on family outcomes conditional on education are very weak. Education itself appears to be playing a central role in driving socioeconomic differences in family behavior-the results here are consistent with the hypothesis that economic advantages themselves promote family stability.

\footnotetext{
${ }^{13}$ A survey of this literature is included in Lundberg (2013b). Locus of control is also stable over the short- and medium term and changes observed in longitudinal data are unrelated to demographic, labor market, and health events (Cobb-Clark and Schurer, 2013).
} 


\section{References}

Almlund, Mathilde, Angela Lee Duckworth, James J. Heckman, and Tim D. Kautz. 2011. Personality Psychology and Economics. In Handbook of the Economics of Education, Volume 4, ed. Eric A. Hanushek, Stephen Machin and Ludger Woessmann, 1-182. Amsterdam, North Holland: Elsevier Science.

American Psychological Association. 2007. APA Dictionary of Psychology. Washington, DC: American Psychological Association.

Becker, Anke, Thomas Deckers, Thomas Dohmen, Armin Falk, and Fabian Kosse. 2012. The Relationship Between Economic Preferences and Psychological Personality Measures. Annual Review of Economics, Vol. 4, 2012: 453-478.

Blazys, Giedrius. 2009. Personality, Intelligence, and Marital Outcomes. Working Paper, University of Washington, 2009.

Carlson, Marcia, Sara McLanahan, Paula England, and Barbara Devaney. 2005. What We Know About Unmarried Parents: Implications for Building Strong Families Programs. Washington DC: Mathematica Policy Research, Inc.

Cherlin, Andrew. 2009. The Marriage-Go-Round: The State of Marriage and the Family in America Today. New York: Alfred A. Knopf.

Chetty, Raj, Nathaniel Hendren, Patrick Kline, and Emmanuel Saez. 2014. Where is the Land of Opportunity? The Geography of Intergenerational Mobility in the United States. WP \#19843. National Bureau of Economic Research.

Chua, Amy, and Jed Rubenfeld. 2014. The Triple Package: How Three Unlikely Traits Explain the Rise and Fall of Cultural Groups in America. Penguin.

Cobb-Clark, Deborah A., and Stefanie Schurer. 2013. Two Economists' Musings on the Stability of Locus of Control. The Economic Journal 123, no. 570: F358-F400.

Cobb-Clark, Deborah A., and Michelle Tan. 2011. "Noncognitive Skills, Occupational Attainment, and Relative Wages." Labour Economics 18, no. 1: 1-13.

Conti, Gabriella, and James J. Heckman. 2010. "Understanding the Early Origins of the Education-Health Gradient A Framework That Can Also Be Applied to Analyze Gene-Environment Interactions." Perspectives on Psychological Science 5, no. 5: 585-605.

Copen, Casey E., Kimberly Daniels, Jonathan Vespa, and William D. Mosher. 2012. "First Marriages in the United States: Data from the 2006-2010 National Survey of Family Growth,” National Health Statistics Reports 49: 1-22.

Costa, P.T. and McCrae, R.R. 1992. NEO PI-R Professional Manual. Odessa FL: Psychological Assessment Resources.

Cunha, Flavio, James J. Heckman, Lance Lochner, and Dimitriy V. Masterov. 2006.Interpreting the evidence on life cycle skill formation. Handbook of the Economics of Education 1: 697-812. 
Dohmen, Thomas, Armin Falk, David Huffman, Uwe Sunde, Jürgen Schupp, and Gert G. Wagner. 2011. Individual Risk Attitudes: Measurment, Determinants, and Behavioral Consequences. Journal of the European Economic Association 9, no. 3: 522-550.

Duncan, Greg J. and Katherine Magnuson. 2011. The Nature and Impact of Early Achievement Skills, Attention Skills, and Behavior Problems. In Whither Opportunity? Rising Inequality, Schools, and Children's Life Chances, ed. Greg .J. Duncan and Richard J. Murnane, 47-70. New York: Russell Sage Foundation.

Fortin, Nicole M. 2008. The Gender Wage Gap among Young Adults in the United States The Importance of Money versus People. Journal of Human Resources, 43, no. 4: 884-918.

Fortin, Nicole, Thomas Lemieux, and Sergio Firpo. 2011. Decomposition methods in economics. Handbook of Labor Economics 4: 1-102.

Goldberg, Lewis R. 1981. Language and Individual Differences: The Search for Universals in Personality Lexicons. In Review of Personality and Social Psychology, Vol. 2, ed. Ladd Wheeler, 141-165. Beverly Hills, CA: Sage.

Gottman, John M. 1994. What Predicts Divorce? The Relationship Between Marital Process and Marital Outcomes. Hillsdale, NJ: Lawrence Erlbaum.

Heckman, James J. 2000. Policies to Foster Human Capital. Research in Economics 54, no. 1: 3-56.

Heckman, James J., Jora Stixrud, and Sergio Urzua. 2006. The Effects of Cognitive and Noncognitive Abilities on Labor Market Outcomes and Social Behavior. Journal of Labor Economics 24, no. 3: 411-82.

Isen, Adam, and Betsey Stevenson. 2011. Women's Education and Family Behavior: Trends in Marriage, Divorce, and Fertility, in John B. Shoven, ed. Demography and the Economy. Chicago: University of Chicago Press, 107-140.

Jann, Ben. 2008. The Blinder-Oaxaca Decomposition for Linear Regression Models. The Stata Journal 8, no. 4: 453-479.

Kambourov, Georgui, Aloysius Siow, and Laura Turner. 2013. Relationship Skills in the Labor and Marriage Markets.

Kornrich, Sabino, and Frank Furstenberg. 2013. Investing in Children: Changes in Parental Spending on Children, 1972-2007, Demography 50(1): 1-23.

Lahey, Benjamin B. 2009. Public Health Significance of Neuroticism. American Psychologist 64, no. 4: 241.

Lundberg, Shelly. 2012. Personality and Marital Surplus. IZA Journal of Labor Economics 1, no. 3.

Lundberg, Shelly. 2013a. The College Type: Personality and Educational Inequality. Journal of Labor Economics 31, no. 3: 421-441.

Lundberg, Shelly. 2013b. Educational Inequality and the Returns to Skills. IZA DP 7595. 
Lundberg, Shelly, and Robert A. Pollak. 2007. American Family and Family Economics, Journal of Economic Perspectives 21(2): 3-26.

Lundberg, Shelly and Robert A. Pollak. 2014. The Uneven Retreat from Marriage in the U.S., 1950-2010, forthcoming in Human Capital and History: The American Record, eds. Leah P. Boustan, Carola Frydman, and Robert A. Margo.

McLanahan, Sara. 2004. Diverging Destinies: How Children Are Faring Under the Second Demographic Transition, Demography 41(4): 607-627.

Miller, Joshua D., Donald R. Lyman, Thomas A. Widiger, and Carl Leukefeld. 2001. Personality Disorders as Extreme Variants of Common Personality Dimensions: Can the Five Factor Model Adequately Represent Psychopathy?. Journal of Personality 69, no. 2: 253-276.

Plotnick, Robert D. 1992. The effects of attitudes on teenage premarital pregnancy and its resolution. American Sociological Review: 800-811.

Ramey, Garey and Valerie A. Ramey. 2010. The Rug Rat Race, Brookings Papers on Economic Activity Spring: 129-176.

Roberts, Brent W. 2009. Back to the Future: Personality and Assessment and Personality Development. Journal of Research in Personality 43, no. 2: 137-45.

Roberts, Brent W.; Caspi, Avshalom; Moffitt, Terrie E. 2003. Work experiences and personality development in young adulthood. Journal of Personality and Social Psychology 84, no. 3: 582-593.

Roberts, Brent W., Nathan R. Kuncel, Rebecca Shiner, Avshalom Caspi, and Lewis R. Goldberg. 2007. The Power of Personality: The Comparative Validity of Personality Traits, Socioeconomic Status, and Cognitive Ability for Predicting Important Life Outcomes. Perspectives on Psychological Science 2, no. 4: 313-45.

Rustichini, Aldo, Colin G. DeYoung, Jon Anderson, and Stephen V. Burks. 2012. Toward the Integration of Personality Theory and Decision Theory in the Explanation of Economic and Health Behavior. IZA DP. 6750 .

Sinning, Mathias, Markus Hahn, and Thomas K. Bauer. 2008. The Blinder-Oaxaca decomposition for nonlinear regression models. The Stata Journal 8, no. 4 (2008): 480-492.

Stevenson, Betsey, and Justin Wolfers. 2007. Marriage and Divorce: Changes and their Driving Forces, Journal of Economic Perspectives 21(2): 27-52.

Wood, Robert G., Sheena McConnell, Quinn Moore, Andrew Clarkwest, and JoAnn Hsueh. 2012. The effects of building strong families: A healthy marriage and relationship skills education program for unmarried parents. Journal of Policy Analysis and Management 31, no. 2: 228-252. 
Table 1a: Effects of Education and Skills on Women's Family Status, Linear Probability Model

\begin{tabular}{|c|c|c|c|c|c|c|c|c|}
\hline & Union & Union & Cohabiting & Cohabiting & $\begin{array}{c}2+ \\
\text { Relation- } \\
\text { ships } \\
\end{array}$ & $\begin{array}{c}2+ \\
\text { Relation- } \\
\text { ships } \\
\end{array}$ & $\begin{array}{l}\text { Single } \\
\text { Mom }\end{array}$ & $\begin{array}{l}\text { Single } \\
\text { Mom }\end{array}$ \\
\hline \multirow[t]{2}{*}{ Some College } & -0.046 & $-0.048^{*}$ & -0.018 & -0.018 & $-0.077^{\ldots *}$ & $-0.074^{\cdots}$ & $-0.065^{\cdots}$ & -0.059 \\
\hline & $(0.024)$ & $(0.024)$ & $(0.023)$ & $(0.023)$ & $(0.026)$ & $(0.026)$ & $(0.023)$ & $(0.023)$ \\
\hline \multirow[t]{2}{*}{ College Graduate } & $-0.071^{\cdots}$ & $-0.085^{\cdots}$ & $-0.087^{\cdots \cdot}$ & $-0.084^{\cdots}$ & $-0.316^{\cdots}$ & $-0.308^{\cdots}$ & $-0.244^{\cdots}$ & $-0.228^{\cdots}$ \\
\hline & $(0.023)$ & $(0.025)$ & $(0.021)$ & $(0.022)$ & $(0.024)$ & $(0.025)$ & $(0.019)$ & $(0.020)$ \\
\hline \multirow[t]{2}{*}{ Openness } & & $-0.021^{*}$ & & 0.010 & & 0.007 & & 0.002 \\
\hline & & $(0.010)$ & & $(0.009)$ & & $(0.010)$ & & $(0.008)$ \\
\hline \multirow[t]{2}{*}{ Conscientiousness } & & 0.016 & & -0.003 & & -0.002 & & -0.002 \\
\hline & & $(0.010)$ & & $(0.008)$ & & $(0.009)$ & & $(0.007)$ \\
\hline \multirow[t]{2}{*}{ Extraversion } & & -0.004 & & 0.001 & & $0.033^{\cdots}$ & & $0.020^{\circ}$ \\
\hline & & $(0.010)$ & & $(0.009)$ & & $(0.010)$ & & $(0.008)$ \\
\hline \multirow[t]{2}{*}{ Agreeableness } & & 0.001 & & -0.008 & & $-0.031^{*}$ & & -0.022 \\
\hline & & $(0.012)$ & & $(0.011)$ & & $(0.012)$ & & $(0.010)$ \\
\hline \multirow[t]{2}{*}{ Emotional Stability } & & 0.011 & & $-0.030^{*}$ & & $-0.038^{\cdots}$ & & -0.014 \\
\hline & & $(0.014)$ & & $(0.013)$ & & $(0.014)$ & & $(0.011)$ \\
\hline \multirow[t]{2}{*}{ Locus of Control } & & $0.040 \ldots$ & & $0.023^{* *}$ & & 0.024 & & -0.006 \\
\hline & & $(0.012)$ & & $(0.010)$ & & $(0.012)$ & & $(0.010)$ \\
\hline \multirow[t]{2}{*}{ Anxiety } & & -0.005 & & -0.007 & & 0.010 & & -0.007 \\
\hline & & $(0.013)$ & & $(0.012)$ & & $(0.013)$ & & $(0.010)$ \\
\hline \multirow[t]{2}{*}{ Anger/Hostility } & & 0.013 & & -0.010 & & -0.015 & & 0.015 \\
\hline & & $(0.014)$ & & $(0.012)$ & & $(0.014)$ & & $(0.011)$ \\
\hline \multirow[t]{2}{*}{ Risk Aversion } & & $0.025^{\circ}$ & & $-0.026^{*}$ & & $-0.040 \cdots$ & & -0.000 \\
\hline & & $(0.010)$ & & $(0.009)$ & & $(0.010)$ & & $(0.008)$ \\
\hline \multirow[t]{2}{*}{ Cognitive Ability } & & -0.006 & & -0.005 & & 0.002 & & 0.009 \\
\hline & & $(0.011)$ & & $(0.009)$ & & $(0.010)$ & & $(0.008)$ \\
\hline Observations & 3831 & 3831 & 3831 & 3831 & 3831 & 3831 & 3831 & 3831 \\
\hline Adjusted $R^{2}$ & 0.003 & 0.026 & 0.008 & 0.025 & 0.078 & 0.103 & 0.078 & 0.084 \\
\hline
\end{tabular}

Sample is white, non-Hispanic men in Wave IV. Model also includes age dummies. 
Table 1b: Effects of Education and Skills on Men's Family Status, Linear Probability Model

\begin{tabular}{|c|c|c|c|c|c|c|}
\hline & Union & Union & Cohabiting & Cohabiting & $\begin{array}{c}2+ \\
\text { Relation- } \\
\text { ships } \\
\end{array}$ & $\begin{array}{c}2+ \\
\text { Relation- } \\
\text { ships } \\
\end{array}$ \\
\hline Some College & $\begin{array}{c}-0.018 \\
(0.025)\end{array}$ & $\begin{array}{l}-0.017 \\
(0.026)\end{array}$ & $\begin{array}{l}-0.037^{\circ} \\
(0.022)\end{array}$ & $\begin{array}{l}-0.032 \\
(0.022)\end{array}$ & $\begin{array}{c}-0.083 \\
(0.026)\end{array}$ & $\begin{array}{c}-0.093 \cdots \\
(0.026)\end{array}$ \\
\hline College Graduate & $\begin{array}{c}-0.0699^{\cdots} \\
(0.026)\end{array}$ & $\begin{array}{c}-0.0688^{*} \\
(0.028)\end{array}$ & $\begin{array}{c}-0.065 \cdots \\
(0.022)\end{array}$ & $\begin{array}{l}-0.050 . \\
(0.022)\end{array}$ & $\begin{array}{c}-0.274 \cdots \\
(0.024)\end{array}$ & $\begin{array}{c}-0.285^{\cdots} \\
(0.025)\end{array}$ \\
\hline Openness & & $\begin{array}{c}-0.054 \cdots \\
(0.011)\end{array}$ & & $\begin{array}{c}0.009 \\
(0.009)\end{array}$ & & $\begin{array}{l}0.033^{\cdots} \\
(0.010)\end{array}$ \\
\hline Conscientiousness & & $\begin{array}{l}-0.012 \\
(0.011)\end{array}$ & & $\begin{array}{l}-0.003 \\
(0.009)\end{array}$ & & $\begin{array}{c}0.002 \\
(0.010)\end{array}$ \\
\hline Extraversion & & $\begin{array}{l}0.028 \\
(0.011)\end{array}$ & & $\begin{array}{l}0.039^{\cdots} \\
(0.009)\end{array}$ & & $\begin{array}{l}0.023 \\
(0.011)\end{array}$ \\
\hline Agreeableness & & $\begin{array}{l}-0.024: " \\
(0.012)\end{array}$ & & $\begin{array}{c}-0.032 \cdots \\
(0.010)\end{array}$ & & $\begin{array}{l}-0.001 \\
(0.012)\end{array}$ \\
\hline Emotional Stability & & $\begin{array}{c}0.013 \\
(0.018)\end{array}$ & & $\begin{array}{l}-0.011 \\
(0.015)\end{array}$ & & $\begin{array}{l}-0.040 \\
(0.017)\end{array}$ \\
\hline Locus of Control & & $\begin{array}{l}0.047^{\cdots} \\
(0.013)\end{array}$ & & $\begin{array}{l}-0.000 \\
(0.011)\end{array}$ & & $\begin{array}{c}0.004 \\
(0.012)\end{array}$ \\
\hline Anxiety & & $\begin{array}{l}-0.021 \\
(0.014)\end{array}$ & & $\begin{array}{l}0.026 \\
(0.011)\end{array}$ & & $\begin{array}{l}-0.007 \\
(0.014)\end{array}$ \\
\hline Anger/Hostility & & $\begin{array}{l}0.038 \\
(0.015)\end{array}$ & & $\begin{array}{l}-0.012 \\
(0.012)\end{array}$ & & $\begin{array}{l}-0.002 \\
(0.014)\end{array}$ \\
\hline Risk Aversion & & $\begin{array}{l}0.037^{\cdots} \\
(0.011)\end{array}$ & & $\begin{array}{l}-0.014 \\
(0.009)\end{array}$ & & $\begin{array}{c}-0.037^{\cdots} \\
(0.011)\end{array}$ \\
\hline Cognitive Ability & & $\begin{array}{c}0.023 \\
(0.012)\end{array}$ & & $\begin{array}{l}-0.009 \\
(0.010)\end{array}$ & & $\begin{array}{c}0.006 \\
(0.011)\end{array}$ \\
\hline Observations & 3483 & 3483 & 3483 & 3483 & 3483 & 3483 \\
\hline Adjusted $R^{2}$ & 0.003 & 0.044 & 0.004 & 0.021 & 0.057 & 0.079 \\
\hline
\end{tabular}


Table 2: Decomposition of the Education Gap in Family Status: High vs. Medium

\begin{tabular}{|c|c|c|c|c|c|c|c|}
\hline & \multicolumn{4}{|c|}{ Women } & \multicolumn{3}{|c|}{ Men } \\
\hline & Union & Cohabiting & $\begin{array}{c}2+ \\
\text { Relationships } \\
\end{array}$ & Single Mom & Union & Cohabiting & $\begin{array}{c}2+ \\
\text { Relationships } \\
\end{array}$ \\
\hline \multicolumn{8}{|l|}{ Means by Own Education } \\
\hline College or More & 0.6813 & 0.1578 & 0.2071 & 0.0380 & 0.5759 & 0.1761 & 0.1799 \\
\hline Some College & 0.7063 & 0.2260 & 0.4466 & 0.2165 & 0.6263 & 0.2044 & 0.3712 \\
\hline Raw Difference & -0.0251 & $-0.0682^{* * *}$ & $-0.2395^{* * *}$ & $-0.1786^{* * *}$ & $-0.0505^{*}$ & -0.0283 & $-0.1913^{* * *}$ \\
\hline \multirow[t]{2}{*}{ Differences in Characteristics } & $0.0150^{*}$ & 0.0003 & 0.0051 & $-0.0107^{*}$ & 0.0096 & 0.0001 & -0.0034 \\
\hline & {$[-0.598]$} & {$[-0.004]$} & {$[-0.021]$} & {$[0.060]$} & {$[-0.258]$} & {$[-0.003]$} & {$[0.018]$} \\
\hline Non-Cognitive Skills & $0.0135^{*}$ & 0.0052 & 0.0072 & $-0.0142^{* * *}$ & -0.0056 & 0.0003 & -0.0002 \\
\hline Cognitive Ability & -0.0027 & --0.0012 & -0.0002 & 0.0013 & $0.0071^{*}$ & 0.0001 & -0.0011 \\
\hline Risk Aversion & 0.0030 & -0.0012 & $-0.0037^{*}$ & 0.0019 & 0.0043 & 0.0002 & -0.0009 \\
\hline \multirow[t]{2}{*}{ Differences in Coefficients } & $-0.0401^{*}$ & $-0.0686^{* * *}$ & $-0.2446^{* * *}$ & $-0.1678^{* * *}$ & -0.0601 * * & -0.0284 & $-0.1879^{* * *}$ \\
\hline & [1.598] & {$[1.006]$} & [1.021] & {$[0.940]$} & [1.258] & [1.997] & [0.982] \\
\hline Age & $0.1724^{* *}$ & -0.0286 & $-0.1239^{*}$ & $-0.0974^{* *}$ & -0.0010 & 0.0171 & 0.0840 \\
\hline Constant & $-0.2152^{* * *}$ & -0.0684 & $-0.1382^{*}$ & $-0.0798^{* *}$ & -0.0687 & -0.0266 & $-0.3091^{* * *}$ \\
\hline
\end{tabular}

Note: p-values in parentheses. Percentage of raw difference explained in brackets.

${ }^{* * *} \mathrm{p}<0.01,{ }^{* *} \mathrm{p}<0.05,{ }^{*} \mathrm{p}<0.1$

Samples are white, non-Hispanic women and men in Wave IV. 
Table 3: Decomposition of the Education Gap in Family Status: High vs. Low

\begin{tabular}{|c|c|c|c|c|c|c|c|}
\hline & \multicolumn{4}{|c|}{ Women } & \multicolumn{3}{|c|}{ Men } \\
\hline & Union & Cohabiting & $\begin{array}{c}2+ \\
\text { Relationships }\end{array}$ & Single Mom & Union & Cohabiting & 2+ Relationships \\
\hline \multicolumn{8}{|l|}{ Means by Own Education } \\
\hline College or More & 0.6813 & 0.1578 & 0.2071 & 0.0380 & 0.5759 & 0.1761 & 0.1799 \\
\hline High School or Less & 0.7526 & 0.2443 & 0.5234 & 0.2818 & 0.6448 & 0.2412 & 0.4537 \\
\hline Raw Difference & $-0.0713^{* * *}$ & $-0.0866^{* * *}$ & $-0.3162^{* * *}$ & $-0.2438^{* * *}$ & $-0.0690^{* * *}$ & $-0.0651^{* * *}$ & $-0.2738^{* * *}$ \\
\hline \multicolumn{8}{|l|}{ Differences in } \\
\hline \multirow[t]{2}{*}{ Characteristics } & 0.0135 & 0.0005 & -0.0045 & -0.0105 & 0.0064 & $-0.0288^{* *}$ & 0.0087 \\
\hline & {$[-0.189]$} & {$[-0.006]$} & {$[0.014]$} & [0.043] & {$[-0.093]$} & [0.442] & {$[-0.032]$} \\
\hline Non-Cognitive Skills & $0.0179^{*}$ & 0.0055 & -0.0112 & $-0.0174^{* *}$ & $-0.0211^{*}$ & $-0.0293^{* * *}$ & -0.0006 \\
\hline Cognitive Ability & -0.0073 & 0.0008 & 0.0112 & 0.0051 & 0.0114 & 0.0014 & 0.0121 \\
\hline Risk Aversion & 0.0009 & $-0.0050^{*}$ & -0.0047 & 0.0004 & 0.0037 & -0.0014 & -0.0029 \\
\hline Differences in Coefficients & $\begin{array}{c}-0.0848^{* * *} \\
{[1.189]}\end{array}$ & $\begin{array}{c}-0.0871^{* * *} \\
{[1.006]}\end{array}$ & $\begin{array}{c}-0.3118^{* * *} \\
{[0.986]}\end{array}$ & $\begin{array}{c}-0.2333^{* * *} \\
{[0.957]}\end{array}$ & $\begin{array}{c}-0.0626^{* *} \\
{[1.093]}\end{array}$ & $\begin{array}{l}-0.0363 \\
{[0.558]}\end{array}$ & $\begin{array}{c}-0.2826^{* * *} \\
{[1.032]}\end{array}$ \\
\hline Age & 0.0778 & $-0.1697^{* *}$ & $-0.1459^{*}$ & -0.0145 & 0.1509 & 0.1220 & 0.1120 \\
\hline Constant & $-0.1765^{* *}$ & 0.0466 & $-\left(-20.2090^{* *}\right.$ & $-0.2411^{* * *}$ & $-0.2402^{* *}$ & -0.1462 & $-0.4071^{* * *}$ \\
\hline
\end{tabular}

Note: Percentage of raw difference explained in brackets.

* * * $\mathrm{p}<0.01,{ }^{*}{ }^{*} \mathrm{p}<0.05,{ }^{*} \mathrm{p}<0.1$

Samples are white, non-Hispanic women and men in Wave IV. 


\begin{tabular}{|c|c|c|c|c|c|c|c|}
\hline & \multicolumn{7}{|c|}{ Women } \\
\hline & $\begin{array}{c}\text { Years of } \\
\text { Education }\end{array}$ & Cohabiting & $\begin{array}{c}\text { Cohabiting } \\
\text { (incl. } \\
\text { education) }\end{array}$ & $\begin{array}{c}2^{+} \\
\text {Relationships }\end{array}$ & $\begin{array}{c}2+ \\
\text { Relationships } \\
\text { (incl. } \\
\text { education) }\end{array}$ & Single Mom & $\begin{array}{l}\text { Single Mom } \\
\text { (incl. } \\
\text { education) }\end{array}$ \\
\hline \multicolumn{8}{|l|}{ Means by Mother's Education } \\
\hline Some College or More & 15.26 & 0.1742 & & 0.3145 & - & 0.1141 & - \\
\hline High School & 13.83 & 0.2276 & & 0.3936 & - & 0.1823 & - \\
\hline Raw Difference & $1.44^{* * *}$ & $-0.0534^{* * *}$ & & $-0.0790^{* * *}$ & - & $-0.0682^{* * *}$ & - \\
\hline \multirow[t]{2}{*}{ Differences in Characteristics } & $0.21 * * *$ & -0.0002 & $-0.0156^{* *}$ & -0.0094 & $-0.0771^{* * *}$ & $-0.0083^{*}$ & $-0.0562^{* * *}$ \\
\hline & {$[0.15]$} & {$[0.004]$} & [0.292] & [0.119] & {$[0.976]$} & {$[0.122]$} & {$[0.887]$} \\
\hline Non-Cognitive Skills & $0.13^{* * *}$ & -0.0027 & -0.0012 & -0.0073 & -0.0012 & -0.0047 & -0.0004 \\
\hline Cognitive Ability & $0.11^{* * *}$ & -0.0008 & 0.0005 & -0.0038 & 0.0023 & -0.0030 & 0.0015 \\
\hline Risk Aversion & -0.01 & 0.0013 & 0.0012 & 0.0035 & 0.0031 & 0.0000 & -0.0003 \\
\hline Own Education & & & $-0.0179^{* * *}$ & & $-0.0790^{* * *}$ & & $-0.0562^{* * *}$ \\
\hline \multirow[t]{2}{*}{ Differences in Coefficients } & $1.22^{* * *}$ & $0.0532^{* * *}$ & $-0.0378^{* *}$ & $-0.0696^{* * *}$ & -0.0019 & -0.0599 * * * & -0.0120 \\
\hline & {$[0.85]$} & [0.996] & [0.708] & [0.881] & [0.024] & {$[0.878]$} & [0.113] \\
\hline Age & 0.07 & 0.0212 & 0.0166 & -0.0165 & -0.0170 & -0.0222 & -0.0168 \\
\hline Constant & $1.06^{* * *}$ & -0.0931 & -0.0635 & -0.0546 & 0.0204 & -0.0278 & 0.0402 \\
\hline
\end{tabular}

Note: Percentage of raw difference between groups explained in bold brackets.

*** $\mathrm{p}<0.01,{ }^{* *} \mathrm{p}<0.05,{ }^{*} \mathrm{p}<0.1$

Sample is white, non-Hispanic women in Wave IV. 
Table 4b: Decomposition of Family Background Gap in Education and Family Status: High vs. Low

\begin{tabular}{|c|c|c|c|c|c|c|c|}
\hline & \multicolumn{7}{|c|}{ Women } \\
\hline & $\begin{array}{c}\text { Years of } \\
\text { Education }\end{array}$ & Cohabiting & $\begin{array}{l}\text { Cohabiting } \\
\text { (incl. } \\
\text { education) }\end{array}$ & $\begin{array}{c}2+ \\
\text { Relationships }\end{array}$ & $\begin{array}{c}2+ \\
\text { Relationships } \\
\text { (incl. } \\
\text { education) } \\
\end{array}$ & Single Mom & $\begin{array}{l}\text { Single Mom } \\
\text { (incl. } \\
\text { education) }\end{array}$ \\
\hline \multicolumn{8}{|l|}{ Means by Mother's Education } \\
\hline Some College or More & 15.26 & 0.1742 & & 0.3145 & - & 0.1141 & - \\
\hline Less than High School & 12.44 & 0.2325 & & 0.5057 & - & 0.2736 & - \\
\hline Raw Difference & $2.82 * * *$ & $-0.0583^{* *}$ & & $-0.1912^{* * *}$ & - & $-0.1595^{* * *}$ & - \\
\hline \multirow[t]{2}{*}{ Differences in Characteristics } & $0.56^{* * *}$ & 0.0050 & $-0.0388^{* *}$ & -0.0461 * * & $-0.1768^{* * *}$ & $-0.0249^{* *}$ & $-0.1210^{* * *}$ \\
\hline & [0.197] & {$[-0.086]$} & [0.666] & {$[0.241]$} & [0.925] & {$[0.156]$} & {$[0.826]$} \\
\hline Non-Cognitive Skills & $0.29^{* * *}$ & 0.0067 & 0.0126 & $-0.0288^{* * *}$ & -0.0117 & $-0.0163^{*}$ & -0.0034 \\
\hline Cognitive Ability & $0.28^{* * *}$ & -0.0042 & 0.0004 & $-0.0174^{* *}$ & -0.0023 & -0.0090 & 0.0012 \\
\hline Risk Aversion & -0.01 & 0.0023 & 0.0022 & 0.0032 & 0.0027 & 0.0002 & -0.0001 \\
\hline Own Education & & & $-0.0540^{* * *}$ & & $-0.1625^{* * *}$ & & -0.1190 * * * \\
\hline \multirow[t]{2}{*}{ Differences in Coefficients } & $2.27^{* * *}$ & $-0.0633^{* *}$ & -0.0195 & $-0.1451^{* * *}$ & -0.0144 & $-0.1347^{* * *}$ & -0.0385 \\
\hline & [0.803] & [1.086] & [0.334] & [0.759] & {$[0.075]$} & [0.845] & [0.174] \\
\hline Age & $-0.67^{*}$ & -0.0983 & -0.1240 & -0.1131 & -0.1550 & 0.0364 & 0.0003 \\
\hline Constant & $2.95^{* * *}$ & -0.0100 & 0.0621 & -0.0496 & 0.1234 & -0.1817 * * & -0.0799 \\
\hline
\end{tabular}

Note: Percentage of raw difference between groups explained in bold brackets.

*** $\mathrm{p}<0.01,{ }^{* *} \mathrm{p}<0.05,{ }^{*} \mathrm{p}<0.1$

Sample is white, non-Hispanic women in Wave IV. 
Table 5a: Decomposition of Family Background Gap in Education and Family Status: High vs. Medium

\begin{tabular}{|c|c|c|c|c|c|}
\hline & \multicolumn{5}{|c|}{ Men } \\
\hline & $\begin{array}{c}\text { Years of } \\
\text { Education }\end{array}$ & Cohabiting & $\begin{array}{c}\text { Cohabiting } \\
\text { (incl. education) }\end{array}$ & $2+$ Relationships & $\begin{array}{l}2+\text { Relationships } \\
\text { (incl. education) }\end{array}$ \\
\hline \multicolumn{6}{|l|}{ Means by Mother's Education } \\
\hline Some College or More & 14.61 & 0.1995 & & 0.2849 & - \\
\hline High School & 13.26 & 0.2127 & & 0.3766 & - \\
\hline Raw Difference & $1.35^{* * *}$ & -0.0132 & & $-0.0917^{* * *}$ & - \\
\hline \multirow[t]{2}{*}{ Differences in Characteristics } & $0.30^{* * *}$ & -0.0064 & $-0.0164^{*}$ & -0.0067 & $-0.0575^{* * *}$ \\
\hline & {$[0.218]$} & {$[0.485]$} & [1.242] & {$[0.073]$} & [0.627] \\
\hline Non-Cognitive Skills & $0.16 * * *$ & -0.0053 & -0.0033 & -0.0039 & 0.0041 \\
\hline Cognitive Ability & $0.14^{* * *}$ & -0.0008 & 0.0008 & -0.0055 & 0.0013 \\
\hline Risk Aversion & -0.00 & -0.0003 & -0.0003 & 0.0025 & 0.0025 \\
\hline Own Education & & & $-0.0136^{* *}$ & & $-0.0657^{* * *}$ \\
\hline \multirow[t]{3}{*}{ Differences in Coefficients } & $1.06^{* * *}$ & -0.0068 & 0.0032 & $-0.0850^{* * *}$ & -0.0342 \\
\hline & {$[0.782]$} & {$[0.515]$} & {$[-0.242]$} & {$[0.927]$} & {$[0.373]$} \\
\hline & 0.20 & 0.0372 & 0.0375 & -0.0075 & -0.0031 \\
\hline Constant & $0.95^{* *}$ & -0.0514 & -0.0284 & -0.1061 & -0.0641 \\
\hline
\end{tabular}

Note: Percentage of raw difference between groups explained in bold brackets.

${ }^{* * *} \mathrm{p}<0.01,{ }^{*}{ }^{*} \mathrm{p}<0.05,{ }^{*} \mathrm{p}<0.1$

Sample is white, non-Hispanic men in Wave IV. 
Table 5b: Decomposition of Family Background Gap in Education and Family Status: High vs. Low

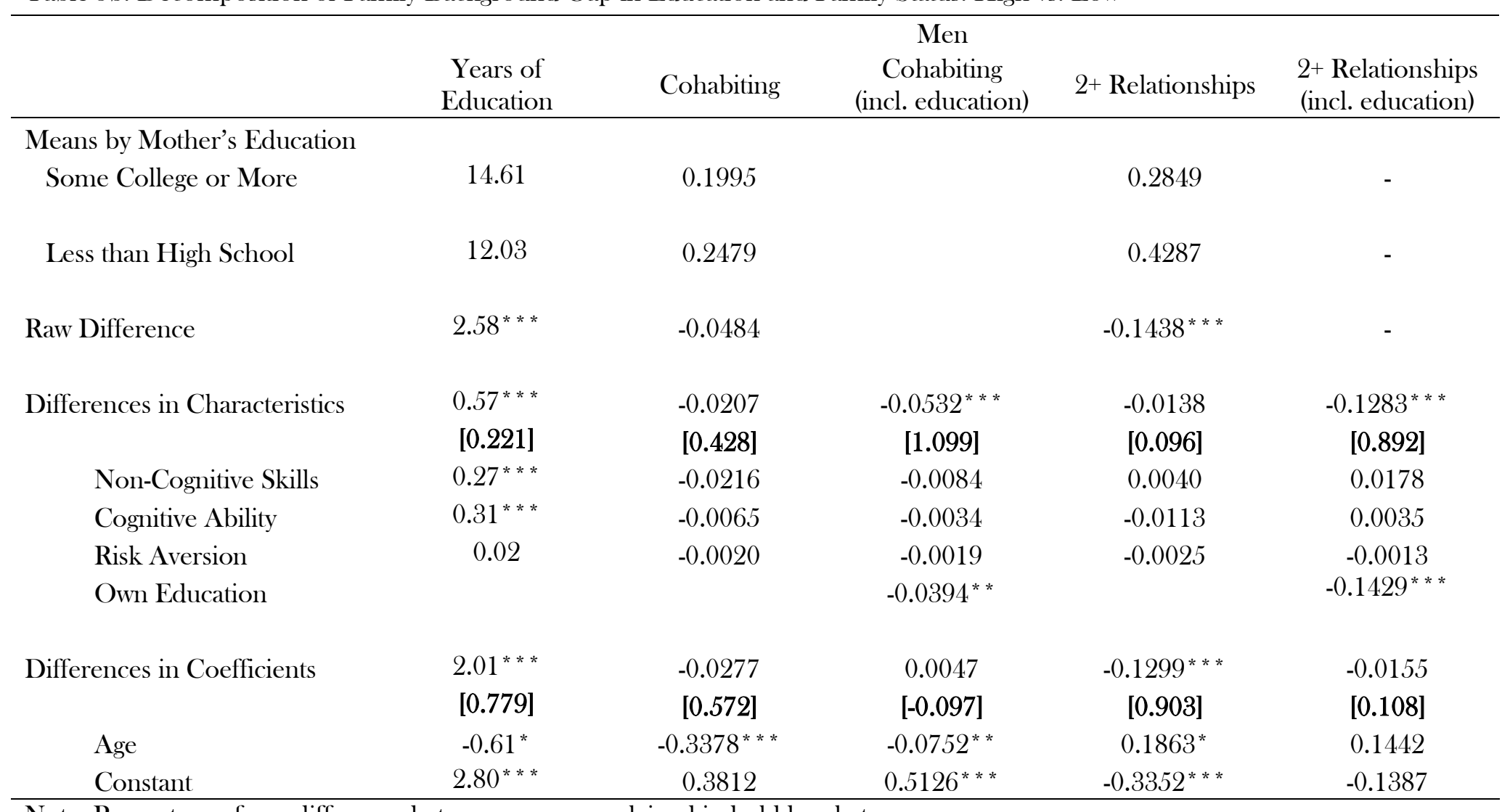

Note: Percentage of raw difference between groups explained in bold brackets.

${ }^{* * *} \mathrm{p}<0.01,{ }^{*}{ }^{*} \mathrm{p}<0.05,{ }^{*} \mathrm{p}<0.1$

Sample is white, non-Hispanic men in Wave IV. 


\section{Data Appendix}

\section{National Longitudinal Survey of Adolescent Health}

National Longitudinal Study of Adolescent Health (Add Health) study began in 1994-95 with a nationallyrepresentative, school-based survey of more than 90,000 students in Grades 7 through 12. About 20,000 respondents were followed in subsequent surveys, the last of which (Wave IV) was conducted in 2007-08 when almost all respondents were between 24 and 32 years of age. The survey content is very rich, initially focusing on the forces influencing adolescent health and risk behaviors and then broadening in scope as the respondents transitioned into adulthood. The study design includes oversamples of ethnic minorities, disabled students, and saturation school samples for the study of social networks. A genetic sample of siblings living in the same household includes twins, siblings, half-siblings, and unrelated pairs such as stepand adopted siblings. The mean age of respondents was 29 at the time of the Wave IV survey (2008Wave IV sampling weights are used in all analyses.

\section{Mother's Education}

The variable called 'mother's education' is the self-reported education level of the individual answering the parent questionnaire in Wave I if that individual is the child's biological mother, step/adoptive/foster mother, or grandmother $(80 \%$ of cases). If the parent questionnaire was completed by the father, or someone else not in one of these categories, then the respondent's own Wave I report of their resident mother's education is used (15\%) or, if this is missing or skipped, their report of biological mother's education level (4\%).

\section{Cognitive Ability}

In Wave I, respondents were given the Add Health Picture Vocabulary Test (AHPVT), a computerized, abridged (87 items) version of the Peabody Picture Vocabulary Test-Revised. In this test, the interviewer reads a word aloud and the respondent selects the illustration that best fits its meaning. A repeat of this test in Wave III has been excluded from the cognitive ability index because it is missing for about $13 \%$ of observations with valid measures for the Wave I AHPVT. The word recall test measures short-term memory (recalling a list of 15 words upon hearing) and long-term memory (recalling the same list after 5 minutes). The number recall test also is a test of short-term memory, that requires the respondent to repeat progressively longer (2 to 8 ) series of digits backwards. The immediate and delayed word recall tasks are standard measures (very similar to the word recall tasks in the Health and Retirement Study) that can be used to study the effect of aging on memory.

Construction of Cognitive Ability Index

\begin{tabular}{lccc}
\hline Question & $\begin{array}{c}\text { Factor } \\
\text { Loading }\end{array}$ & $\begin{array}{c}\text { Unique } \\
\text { Variance }\end{array}$ & $\begin{array}{c}\text { Scoring } \\
\text { Coefficients }\end{array}$ \\
\hline Cognitive Ability & & & \\
AHPVT (Wave I) & 0.4042 & 0.8366 & 0.17977 \\
Word Recall, Short term (Wave IV) & 0.7325 & 0.4634 & 0.58809 \\
Word Recall, Long term (Wave IV) & 0.7330 & 0.4627 & 0.58950 \\
Number Recall (Wave IV) & 0.3842 & 0.8524 & 0.16769 \\
& & & \\
\hline
\end{tabular}




\section{Personality Traits}

The Add Health survey fielded a 20-item short-form version of the 50-item International Personality Item Pool-Five-Factor Model (IPIP-FFM) known as the Mini-IPIP (Donnellan et al., 2006) in the Wave IV survey. Brief personality instruments designed to be included in long surveys tend to have weaker psychometric properties than do full-length personality scales, with some tradeoff between choosing items that provide both construct breadth and high reliability. A recent assessment finds that the Mini-IPIP does have a 5 -factor structure, and that most of the scales have acceptable reliability despite the brevity of the instrument (Baldasaro et al., 2013). The Cronbach's alpha scores for the personality scales in the Add Health sample range from .62 (Neuroticism) to .72 (Extraversion). Also included are the two facets of Emotional Stability-Anger/Hostility and Anxiety-and Locus of Control.

Factor analysis of the survey items included in each personality trait produces the factor loadings reported in the table below, and the scoring coefficients generated by the Bartlett method are used to construct an estimate of each latent trait. ${ }^{14}$

Construction of Non-Cognitive Skill Indices

\begin{tabular}{|c|c|c|c|}
\hline Personality Question & $\begin{array}{l}\text { Factor } \\
\text { Loading }\end{array}$ & $\begin{array}{c}\text { Unique } \\
\text { Variance }\end{array}$ & $\begin{array}{c}\text { Scoring } \\
\text { Coefficients } \\
\text { (Bartlett) }\end{array}$ \\
\hline \multicolumn{4}{|l|}{ Openness $(\alpha=.65)$} \\
\hline I have a vivid imagination & 0.5469 & 0.7008 & 0.42232 \\
\hline I am not interested in abstract ideas (reversed) & 0.5548 & 0.6923 & 0.43366 \\
\hline I have difficulty understanding abstract ideas (reversed) & 0.5448 & 0.7032 & 0.41929 \\
\hline I do not have a good imagination (reversed) & 0.5972 & 0.6433 & 0.50234 \\
\hline \multicolumn{4}{|l|}{ Conscientiousness $(\alpha=.66)$} \\
\hline I get chores done right away & 0.5238 & 0.7257 & 0.4270 \\
\hline I often forget to put things back in their proper place (reversed) & 0.5956 & 0.6452 & 0.5462 \\
\hline I like order & 0.4715 & 0.7777 & 0.3586 \\
\hline I make a mess of things (reversed) & 0.5681 & 0.6772 & 0.4963 \\
\hline \multicolumn{4}{|l|}{ Extraversion $(\alpha=.72)$} \\
\hline I am the life of the party & 0.5375 & 0.7110 & 0.3030 \\
\hline I don't talk a lot (reversed) & 0.5746 & 0.6699 & 0.3438 \\
\hline I talk to a lot of different people at parties & 0.6422 & 0.5875 & 0.4381 \\
\hline I keep in the background (reversed) & 0.6870 & 0.5281 & 0.5214 \\
\hline
\end{tabular}

\footnotetext{
${ }^{14}$ The Bartlett prediction method (Bartlett, 1938) produces unbiased factors that may be less accurate that the those produced by the alternative regression method, which minimizes the mean squared errors from the true factors but may be biased. Aizer and Cunha (2012) use this method to construct a measure of parental investment using several observer ratings of mother/child interaction.
} 
Agreeableness $(\alpha=.71)$

I sympathize with others' feelings

0.5658

0.6799

0.3615

I am not interested in other people's problems (reversed)

0.6441

0.5851

0.4783

I feel others' emotions

0.5736

0.6710

0.3714

I am not really interested in others (reversed)

0.6221

0.6130

0.4409

Neuroticism $(\alpha=.62)$

I have frequent mood swings

0.6332

0.5991

0.6182

I am relaxed most of the time (reversed)

0.4550

0.7930

0.3356

I get upset easily

0.6195

0.6162

0.5880

I seldom feel blue (reversed)

0.3680

0.8646

0.2489

Internal Locus of Control/Mastery

There is little I can do to change the important things in my life

0.6212

0.6142

0.2854

Other people determine most of what I can and cannot do

0.6499

0.5777

0.3175

There are many things that interfere with what I want to do

0.4818

0.7679

0.1771

I have little control over the things that happen to me

0.6976

0.5134

0.3835

There is really no way I can solve the problems I have

0.6949

0.5171

0.3793

Anxiety

I worry about things

0.6208

0.6147

0.4427

I am not easily bothered by things (reversed)

0.5909

0.6509

0.3980

I get stressed out easily

0.6583

0.5667

0.5093

I don't worry about things that have already happened

0.5108

0.7390

0.3030

Anger/Hostility

I get angry easily

$\begin{array}{lll}0.7541 & 0.4314 & 0.4856\end{array}$

I rarely get irritated (reversed)

0.5193

0.7304

0.1975

I lose my temper

0.7497

0.4379

0.4756

I keep my cool (reversed)

0.6213

0.6140

0.2811 